\title{
Changes in the kinematic parameters of gait in children with cerebral palsy after multilevel interventions with the initial patterns of true equinus gait and jump gait
}

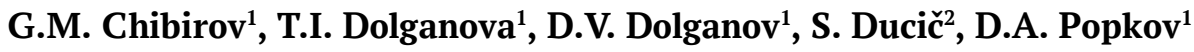

${ }^{1}$ Russian Ilizarov Scientific Centre for Restorative Traumatology and Orthopaedics, Kurgan, Russian Federation, ${ }^{2}$ Children's University Hospital, Belgrade, Serbia

\begin{abstract}
Introduction Cerebral palsy is the most common cause of motor disorders that occurs in early childhood and is present throughout life. The incidence rate of the disease is 1/500 newborns. About 17 million people with cerebral palsy live in the world. According to domestic epidemiologists, the reported incidence of cerebral palsy in Russia is from 2.2 to 3.8 per 1,000 births. Spastic cerebral palsy types are $80 \%$ of all the cases. Purpose Analysis of changes in the kinematic parameters of gait after multilevel interventions in children with cerebral palsy with the initial true equinus gait and jump gait patterns. Material and methods This retrospective study included 64 children (26 girls, 38 boys) with cerebral palsy and spastic diplegia. The average age was $8.7 \pm 2.41$ years. All patients corresponded to levels I or II of impaired motor function (GMFCS: I/II = 14/50). Results All patients showed a significant improvement in the kinematic parameters of gait throughout the observation period. Deviation from the normal values decreased almost four times in the whole group of patients. Conclusion Multilevel single-event orthopedic interventions improve the kinematic and kinetic parameters of the gait of the entire biomechanical chain in the lower extremities. In addition to the local effects of surgical interventions (elimination of orthopedic disorders such as contractures and deformities of bones and joints of the lower extremities), there are long-term changes in the reduction of energy-consumptive compensatory movements.
\end{abstract}

Keywords: cerebral palsy, true equinus gait, jump gait, torsion deformities, orthopedic surgical treatment, gait analysis

\section{INTRODUCTION}

The incidence of cerebral palsy is two to five cases per 1,000 newborns [1-4]. According to Russian epidemiologists, the reported rate of cerebral palsy in Russia is from 2.2 to 3.8 per 1,000 births. Spastic cerebral palsy types are about $80 \%$ of all the cases registered [5-8].

Despite the fact that cerebral palsy is a stable encephalopathy, it is orthopedic complications that are the main cause of progressive motor activity deterioration in children with cerebral palsy [9-11]. The pathogenesis of the disease implies that the initial spastic syndrome gradually leads to muscle retraction and the appearance of contractures requiring surgical treatment. The modern concept of operative orthopedic treatment of children with cerebral palsy is multilevel surgical interventions on all components of the biomechanical chain in the limbs. It makes the child capable to use both limbs while learning to walk correctly or close to correct walking, independent or with auxiliary means [12-17]. Moreover, the methods of operative correction should result in early weightbearing, early passive and active mobilization of the joints after the interventions [18]. Another important point in planning surgical treatment is the analysis of walking disorders. Based on a computer gait analysis, the main pathological patterns in spastic diplegia were identified [19-23]. Lofterød B. et al. [24], Simon S.R. et al. [25] point to the critical importance of gait analysis both for understanding the pathology of movements and for planning surgical interventions and control in the long term period [26].

If computer analysis of kinematic, kinetic and dynamic electroneuromyographic findings is unavailable, observation scales are recommended that are based on studying goniometric findings of motion video recording in orthogonal planes [2729]. Novacheck T.F. et al. [28] and Read H.S. et al. [30] showed that the Edinburgh visual gait score correlates with the Gillette Gait Index and the Gillette Functional Assessment Questionnaire (FAQ), which allows it to be used for clinical purposes given that the experience to work with the 3D gait laboratory analysis has been gained.

We retrospectively examined the results of using single-event multilevel orthopedic surgery (SEMLS) in patients with true equinus gait, jump gait, asymmetric

Chibirov G.M., Dolganova T.I., Dolganov D.V., Ducič S., Popkov D.A. Changes in the kinematic parameters of gait in children with cerebral palsy after multilevel interventions with the initial patterns of true equinus gait and jump gait. Genij Ortopedii, 2019, vol. 25, no 4, pp. 501-509. DOI 10.18019/1028-4427-2019-25-4-501-509. (In Russian) 
gait (a combination of the first two) patterns and compared gait parameters using the Edinburgh scale in the preoperative period, one year after surgery and in the long term. The types of the pathological gait indicated above are similar in parameters, so the results of their surgical correction could be shown together
$[31,32]$. We also should point out that it is impossible to study the effect of a single surgical treatment element on the final result within the framework of SEMLS. Therefore, the impact of surgical correction was studied in the groups of patients with similar interventions and anatomical locations [33, 34].

\section{MATERIAL AND METHODS}

This retrospective study included 64 children (26 girls, 30 boys) that had spastic diplegia due to cerebral palsy. Mean age was $8.7 \pm 2.41$ years. All had either GMFCS level I or II (GMFCS: I/II = 14/50).

The study was conducted in accordance with the ethical standards of the Helsinki Declaration of the World Medical Association "Ethical Principles for Medical Research Involving Human Subjects" as amended in 2013 and the "Rules of Clinical Practice in the Russian Federation", approved by order of the Ministry of Health of the Russian Federation dated June 19, 2003 No. 266. Patients, patients' parents, and / or their legal representatives signed an informed consent for surgery and publication of the data without identification.

All the patients underwent single-event multilevel surgeries. One intervention included an average of $6.3 \pm 1.46$ surgical elements. The elements are given in Table 1. In addition, some patients underwent correction of torsion deformities of the femur in the period from 12 to 15 months after the initial intervention: 12 subjects ( 24 femurs).
Gait analysis using the Edinburgh visual gait score was performed before surgery, one year after the intervention and two to three years after the initial operation.

To determine the functional abilities of independent walking, the Gillette questionnaire (FAQ) [35] was used at the same time.

AtteStat 12.0.5 software was used for statistical data processing. Descriptive statistics showed the average value of the parameter and its standard deviation. Spearman's rank correlation score was used to link the Edinburgh score and FAQ. The chi-square test determined the significance of differences in the Edinburgh scale in patients with or without clinically significant torsion deformities. The specificity and sensitivity of the combination of maximum deviations of the "knee progression angle" - "trunk maximal lateral shift" were determined as a test for identifying indications for surgical correction of torsion deformities of the femur.

Table 1

Elements of primary surgical interventions

\begin{tabular}{|l|c|}
\hline \multicolumn{1}{|c|}{ Surgical element } & Number \\
\hline Lengthening of medial knee flexors & 122 \\
\hline Lengthening of abductors, m. gracilis & 64 \\
\hline M. gastrocnemius aponeurotomy, lengthening of the Achilles tendon & 115 \\
\hline Subtalar arthrodesis & 62 \\
\hline Shortening of m. tibialis posterior tendon & 24 \\
\hline Detorsion osteotomy of the femur & 8 \\
\hline Detorsion osteotomy of the tibia & 8 \\
\hline Total & 403 \\
\hline
\end{tabular}

\section{RESULTS}

Average values of 17 parameters of the Edinburgh scale studied are shown in Table 2. There was a significant improvement in the kinematic gait parameters in children in the period of observation and a four-fold reduction of deviation from the normal values for the whole group. Most significant improvements were observed in the support phase of gait: initial contact, heel lift, maximum dorsiflexion of the foot, peak knee extension, peak hip extension, trunk lateral shift, foot and knee orientation relative to the motion axis while in the non-support phase those were maximum ankle dorsiflexion, peak knee flexion, clearance, peak hip flexion, knee position in terminal swing immediately before the contact with the supporting surface.

Comparison of the total of the Edinburgh scale with FAQ values found a significant negative correlation in 
the period before treatment and two to three years after the initial operation (Table 3). A study of changes in the parameters in patients during the first year after surgery revealed that torsion of the femur which was undetected or unrepaired at the initial stage of treatment, required a repeated intervention in 12 patients 12 to 15 months after the primary operation. Figures 1 and 2 present the distribution of cases depending on gait analysis and FAQ values for a period of 12 months after the initial operation, illustrating the effect of uncorrected torsion on the outcome of treatment in the mid-term followup. As mentioned above, torsion deformities were surgically corrected in 12 patients in the period from 12 to 15 months after the initial intervention.

A separate analysis of the treatment results is presented in Table 4. We believe that the loss of correlation between the changes in motor activity and gait analysis parameters during the period of 12 months after surgery is due to the fact that patients with and without torsion deformity correction were analyzed together. Significant values of negative correlation in the period from two to three years after the initial operation, when torsion had been already eliminated in all patients, lead to the same conclusion.

Thus, multilevel interventions provided a significant improvement in the kinematic parameters of gait analysis in the long-term period both for patients with true equinus gait (Fig. 3) and for children with jump gait (Fig. 4).

When analyzing the results of treatment of patients in whom torsion deformity correction was included in the treatment program, it was found that the combination of maximum deviations in the parameters "knee progression angle" and "trunk maximal lateral shift" of the Edinburgh scale in the initial analysis of gait correlates with clinically significant torsion deformities that were corrected as part of the first intervention or after 1 year. We should stress the high sensitivity and specificity of this combination as a diagnostic test (Table. 5).

Table 2

Average values of Edinburgh visual gait score for the entire group

\begin{tabular}{|l|c|c|c|}
\hline \multicolumn{1}{|c|}{ Parameter } & Before surgery & Follow-up, 12 months & Follow-up, 2-3 years \\
\hline Initial contact & 2.0 & 0.83 & 0.75 \\
\hline Heel lift & 1.93 & 0.7 & 0.5 \\
\hline Maximum ankle dorsiflexion & 1.73 & 0.3 & 0.21 \\
\hline Hind-foot varus/valgus & 1.2 & 0.1 & 0.13 \\
\hline Foot progression angle & 1.43 & 0.77 & 0.54 \\
\hline Knee progression angle & 1.2 & 0.7 & 0.46 \\
\hline Peak knee extension & 1 & 0.13 & 0.13 \\
\hline Peak hip extension & 0.8 & 0.13 & 0.13 \\
\hline Pelvic obliquity at Mid-Stance & 0.93 & 0.63 & 0.5 \\
\hline Pelvic rotation at Mid-Stance & 0.73 & 0.5 & 0.3 \\
\hline Trunk Peak Sagittal Position & 1.07 & 0.6 & 0.58 \\
\hline Trunk maximum lateral shift & 1.53 & 1.23 & 0.75 \\
\hline Clearance & 0.9 & 0.27 & 0.13 \\
\hline Maximum ankle dorsiflexion & 1.47 & 0.4 & 0.33 \\
\hline Peak knee flexion & 1.1 & 0.37 & 0.125 \\
\hline Knee terminal swing position & 1.46 & 0.1 & 0.04 \\
\hline Peak hip flexion & 1.2 & 0.13 & 0.08 \\
\hline Total & $\mathbf{4 2 . 7}$ & $\mathbf{1 5 . 3}$ & $\mathbf{1 1 . 3}$ \\
\hline
\end{tabular}

Table 3

Correlation of Edinburgh scores and FAQ

\begin{tabular}{|l|c|c|c|}
\hline \multicolumn{1}{|c|}{ Period } & Edinburgh score & FAQ & Spearman \\
\hline Before surgery & 42.7 & 3.8 & -0.825 \\
\hline After 12 months & 15.3 & 6.3 & -0.491 \\
\hline After 2-3 years & 11.3 & 7.7 & -0.845 \\
\hline
\end{tabular}



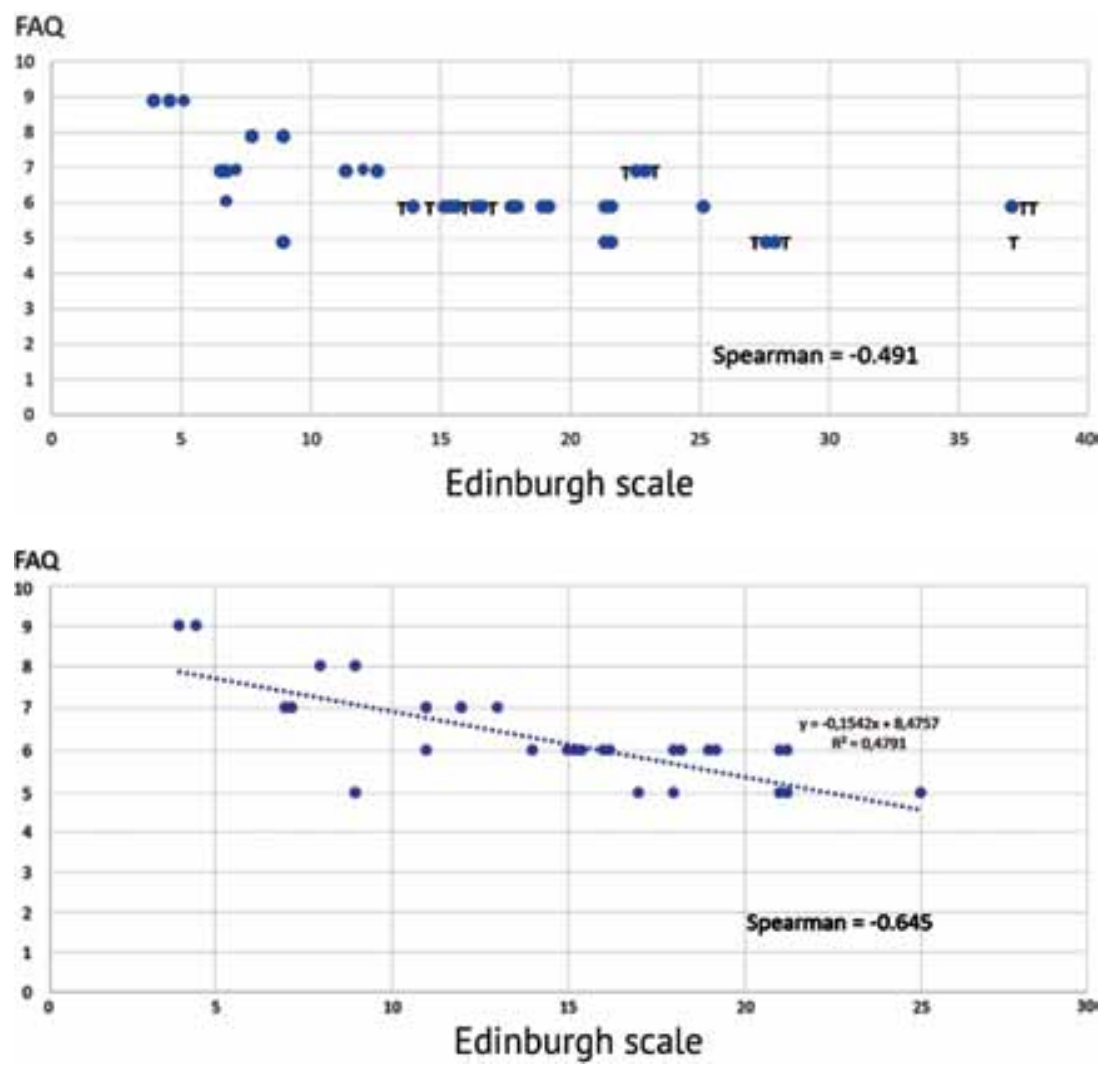

Fig. 1 Distribution of all cases, including torsion deformities not corrected, depending on gait analysis and FAQ values 12 months after the initial intervention. Cases with clinically significant torsion deformities are marked with " $\mathrm{T}$ "

Fig. 2 Distribution of cases without torsion depending on the values of gait analysis and FAQ 12 months after surgery. Inverse correlation values become significant

Table 4

Correlation for Edinburgh scale and FAQ findings are presented separately with or without torsion deformities

\begin{tabular}{|l|c|c|c|c|c|c|}
\hline & \multicolumn{2}{|c|}{ Before treatment } & \multicolumn{2}{c|}{ After 12 months } & \multicolumn{2}{c|}{ After 2-3 years } \\
\cline { 2 - 7 } & Without torsion & With torsion & Without torsion & With torsion & Without torsion & With torsion \\
\hline Edinburgh score & 42.5 & 43.2 & 13.4 & 23.2 & 9.75 & 14.6 \\
\hline FAQ & 3.7 & 4.1 & 6.5 & 6.0 & 7.9 & 7.2 \\
\hline Spearman & $\begin{array}{c}-0.836 \\
(\mathrm{p}=0.9999)\end{array}$ & $\begin{array}{c}-0.873 \\
(\mathrm{p}=0.9995)\end{array}$ & $\begin{array}{c}-0.645 \\
(\mathrm{p}=0.9989)\end{array}$ & $\begin{array}{c}-0.194 \\
(\mathrm{p}=0.7043)\end{array}$ & $\begin{array}{c}-0.842 \\
(\mathrm{p}=0.999)\end{array}$ & $\begin{array}{c}-0.776 \\
(\mathrm{p}=0.9958)\end{array}$ \\
\hline
\end{tabular}

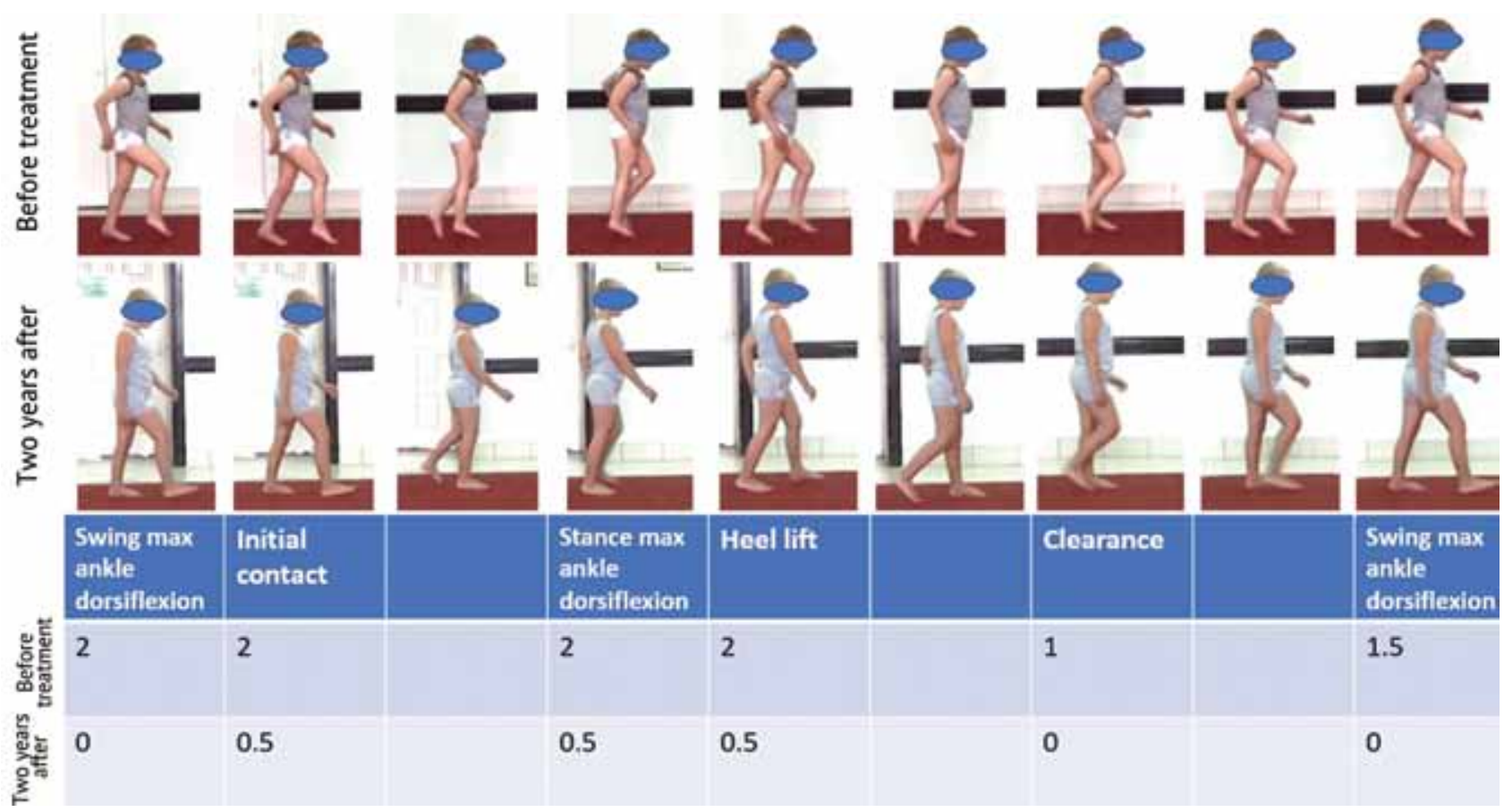

Fig. 3 Changes in gate analysis values in a patients with an initial true equinus gait pattern 


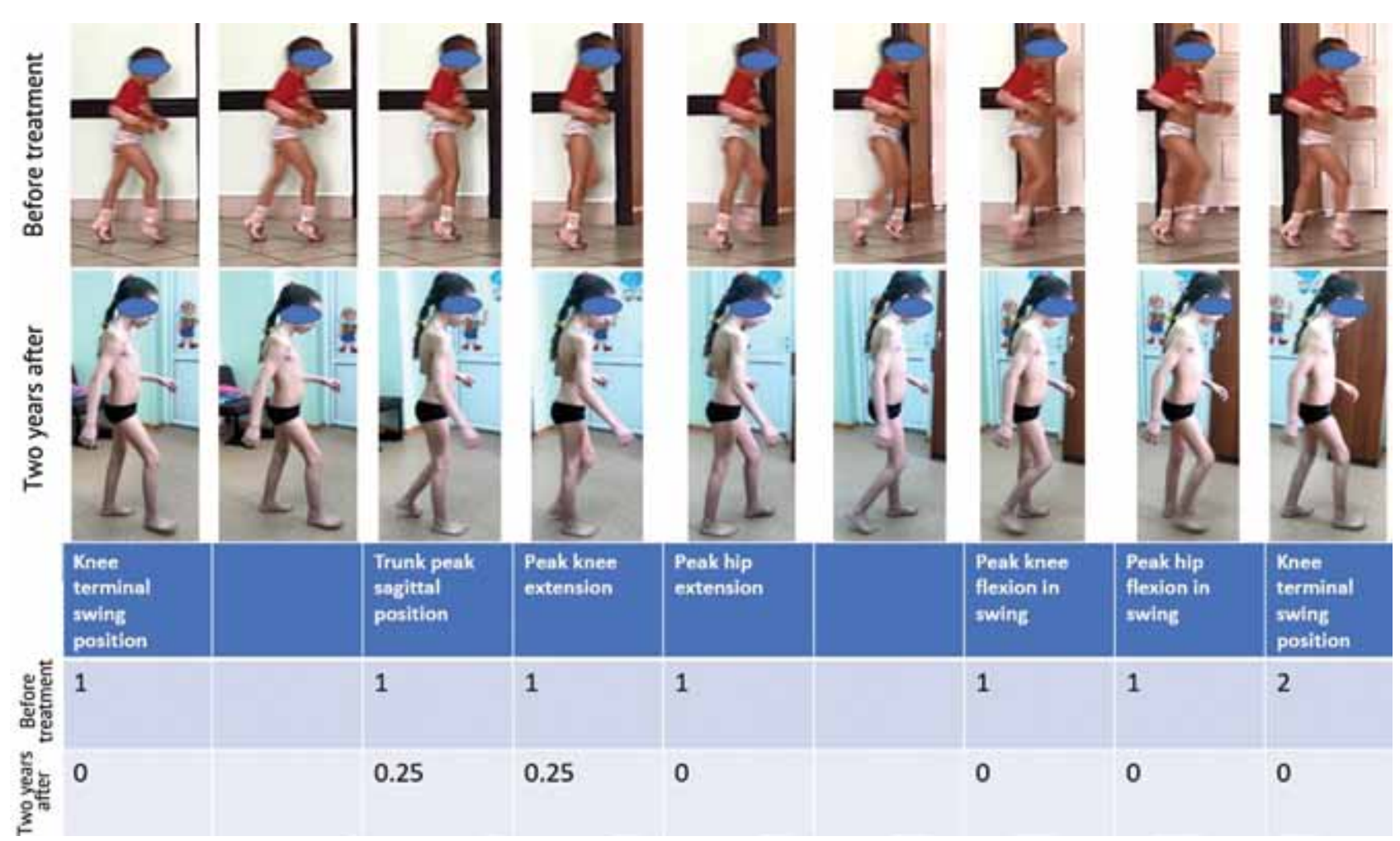

Fig. 4 Changes in gate analysis values in a patients with an initial jump gait pattern

Table 5

Correlation of maximal deviations in parameters "knee progression angle" and "trunk maximal lateral shift" of the Edinburgh scale in the initial gait analysis with clinically significant torsion deformities, prognostic significance

\begin{tabular}{|l|c|c|c|c|c|c|}
\hline & $\begin{array}{c}\text { Knee } \\
\text { progression } \\
\text { angle }\end{array}$ & $\begin{array}{c}\text { Trunk maximum } \\
\text { lateral shift }\end{array}$ & $\begin{array}{c}\text { Incidence of combinations } \\
\text { of maximal deviation in } \\
\text { these parameters, \% }\end{array}$ & Chi-square test & Sensitivity & Specificity \\
\hline No torsion & $0.9 \pm 0.44$ & $1.25 \pm 0.43$ & 7.3 & $\mathrm{p}<0.001$ & 0.772 & 0.921 \\
\hline $\begin{array}{l}\text { Correction of } \\
\text { torsion }\end{array}$ & $1.8 \pm 0.41$ & $2.0 \pm 0.0$ & 84.7 & & & \\
\hline
\end{tabular}

\section{DISCUSSION}

Cerebral palsy is the most common cause of motor disorders that occurs in early childhood and is present throughout life. The incidence rate of the disease is $1 / 500$ newborns. About 17 million people with cerebral palsy live in the world.

Gait disorders, classified as true equinus gait and jump gait, are characteristic of children with spastic diplegia; these patterns are caused by spasticity and/or retraction of the muscles of the plantar flexors of the feet and flexors of the knee joint [22]. In muscle retraction accompanied by critical deterioration of goniometric parameters, surgical orthopedic treatment becomes reasonable [38-40]. However, in addition to muscle retraction, the objects of surgical treatment in multilevel interventions for these types of gait are foot deformities and torsion of segments [41-51].
The main object of orthopedic surgery for true equinus gait and jump gait is the elimination of contractures of the knee and ankle joints of both limbs [29, 32, 52]. In this case, it is extremely important to exclude unreasonable early surgical interventions (muscle lengthening before critical retraction develops; Achilles tendon lengthening in the absence of soleus muscle retraction; surgery in the age under 5-6 years, when, as a rule, there is no retraction of the muscles yet) [32, $53-56]$. Early unreasonable interventions lead to the development of functional insufficiency of the leg triceps, loss of strength of the eccentric contraction of the triceps (especially the soleus muscle) in the support phase of the gait at the time of kinetic energy absorption, which is accompanied by premature flexion in the knee joint and gradual development of extensor 
apparatus failure with the progression of the pattern into the crouch gait [56-58].

The method of choice for triceps lengthening in cerebral palsy is fasciotomy of the calf muscles, which, according to a computer analysis of gait, is accompanied by an improvement in the kinematic parameters of the ankle joint without the development of crouch gait in the long term [52, 57, 59,60]. It is this effect that was observed in our study, gait parameters and foot kinematics improved in all patients without pathological flexion in the knee joint in the long-term period. In this case, it is extremely important to exclude hyper- or hypocorrection of contractures of the knee joints [55].

According to Gorton G.E. et al. [55], Terjesen T. et al. [60], the improvement / normalization of ankle joint motion was not accompanied by compensatory changes in the kinematic parameters of the hip and knee joints. In our study, we noted an improvement in the parameters of movements in the hip and knee joints, regarding this situation as a remote effect of improving the kinematics of the ankle joints and correction of foot deformities.

In particular, normalization/improvement of knee joint extension the before the initial contact, which improves the orientation of the foot at the beginning of the support phase, was also emphasized in a study of Adolfsen S. et al. [31].

Among other positive effects of the operation, we found a decrease in excessive compensatory flexion of the knee and hip joints in the non-support phase in combination with an improvement in clearance, which is a consequence of an increased dorsiflexion of the foot. Previously, other researchers also observed this outcome of the orthopedic intervention $[31,55]$.

Исследования, основанные на изучении кинематических и кинетических параметров походки, показали, что увеличение/нормализация тыльной флексии стопы в опорную фазу сопровождается устранением патологических величин плеч рычагов в сагиттальной плоскости $[30,59]$ и сдвигом момента максимальной генерации энергии концентрического сокращения трицепса к концу опорной фазы [29, 51].

Studies based on the analysis of the kinematic and kinetic gait parameters showed that an increase/ normalization of foot dorsiflexion in the support phase is accompanied by elimination of pathological values of the lever arm in the sagittal plane $[30,59]$ and a shift in the moment of maximum generation of energy of concentric contraction of the triceps to the end of the support phase $[29,51]$.

Ounpuu S. et al. [21], 2002; Theologis T. et al. [61] pointed out the need to eliminate torsion deformities of the limbs to normalize the lever arms in the frontal plane and make walking less energy-consuming. However, with respect to the correction of torsion deformities in children, there is sufficient uncertainty associated with a weak correlation between the anatomical values of torsion and gait analysis parameters [49]. In adult patients with spastic paralysis, the results of correction based on anatomical parameters are much more predictable [62]. Thus, the elimination of torsion deformities may be delayed until the active limb growth is completed [47].

However, clinically significant torsion deformities that cause functional difficulties during regular daily physical activities will require correction in childhood. Interventions on the soft tissues do not results in a significant elimination of pathological rotation of the femur [63]. Our study showed that the criterion for detorsion osteotomy indication as a part of multilevel interventions in children with true equinus gait and jump gait patterns is a combination of extreme deviations of the Edinburgh scale parameters such as knee progression angle with trunk maximum lateral shift in the support phase. This test (criterion) has high specificity and sensitivity.

In general, orthopaedic interventions in children with cerebral palsy is aimed at correction of deformities to improve the biomechnicas of walking, joint contracture elimination for improving daily activities and functional abilities, reduction in power consumption that is due to biomechanical disorders, prevention and decrease of pain due to early arthritis, deformities, elimination of obstacles to use regular footwear and orthoses [47, 62, $64,65,66]$. Analysis of gait kinematic and kinematic parameters makes the surgeon revise the treatment plan by excluding or adding surgical elements [24].

Our study confirms that multilevel interventions significantly improve most gait parameters, both directly dependent on retraction and deformity in a particular anatomical region, and indirectly due to compensatory biomechanically malposition and function of the distant segments. Diagnosis and quantification of torsion deformity should be considered first, which is based in childhood primarily 
on the assessment of the kinematic parameters of gait. Correction of torsion deformities should be performed simultaneously with the elimination of joint contractures and deformities of the feet.

\section{CONCLUSION}

Multilevel single-event orthopedic interventions improve the kinematic and kinetic gait parameters of the entire biomechanical chain in the lower extremities. Along with the local effects of surgical interventions, there are long-term changes in the reduction of energy-consumptive compensatory movements. According to the Edinburgh visual gait score, the combination of maximum deviations of the knee progression angle with trunk maximum lateral shift in the support phase substantiates the indications for correction of torsion deformities. The use of kinetic and kinematic parameters and their analysis based on quantitative data is mandatory in orthopedic surgery of cerebral palsy.

\section{REFERENCES}

1. Alriksson-Schmidt A., Hägglund G. Acta Paediatr., 2016, vol. 105, no. 6, pp. 665-670. DOI: 10.1111/apa.13368.

2. Bottos M., Granato T., Allibrio G., Gioachin C., Puato M.L. Prevalence of cerebral palsy in north-east Italy from 1965 to 1989. Dev. Med. Child. Neurol., 1999, vol. 41, no. 1, pp. 26-39.

3. Cans C. Comprendre la paralysie cérébrale: Qui sommes nous? Combien sommes-nous? La recherche sur l'infirmité motrice cérébrale en Europe. Paris, Fondation Motrice, 2006.

4. Stavsky M., Mor O., Mastrolia S.A., Greenbaum S., Than N.G., Erez O. Cerebral Palsy - Trends in Epidemiology and Recent Development in Prenatal Mechanisms of Disease, Treatment, and Prevention. Front. Pediatr., 2017, vol. 5, pp. 21. DOI: 10.3389/ fped.2017.00021.

5. Guzeva V.I., Kurenkov A.L., Zmanovskvaia V.A., Batysheva T.T., Semenova K.A., Zherebtsova V.A., Vladykina L.N., Popkov D.A. Detskii Tserebralnyi Paralich. Federalnoe Rukovodstvo po Detskoi Nevrologii [Infantile Cerebral Palsy. Federal Guide to Pediatric Neurology]. Ed. by prof. Guzeva V.I. M., 2016, ch. 14, pp.169-185. (in Russian)

6. Zmanovskvaia V.A., Levitina E.V., Popkov D.A., Butorina M.N., Pavlova O.L. Dlitelnoe primenenie preparata botulinicheskogo toksina tipa A: disport v kompleksnoi Reabilitatsii detei so spasticheskimi formami tserebralnogo paralicha [Long use of Type A Botulinum Toxin: disport in complex rehabilitation of children with spastic forms of cerebral palsy]. Zhurnal Nevrologii i Psikhiatrii im. S.S. Korsakova, 2014, vol. 114, no. 7, pp. 33-36. (in Russian)

7. Kurenkov A.L., Klochkova O.A., Zmanovskaia V.A., Falkovskii I.V., Kenis V.M., Vladykina L.N., Krasavina D.A., Nosko A.S., Rychkova L.V., Karimova Kh.M., Bursagova B.I., Namazova-Baranova L.S., Mamediarov A.M., Kuzenkova L.M., Dontsov O.G., Ryzhenkov M.A., Butorina M.N., Pavlova O.L., Kharlamova N.N., Dankov D.M., Levitina E.V., Popkov D.A., Riabykh S.O., Medvedeva S.N., Gubina E.B., Agranovich O.V., Kiseleva T.I., Vasileva O.N., Zykov V.P., Mikhnovich V.I., Belogorova T.A. Pervyi Rossiiskii Konsensus po primeneniiu mnogourovnevykh inektsii Abobotulinumtoxin A pri lechenii spasticheskikh form detskogo tserebralnogo paralicha [The First Russian Consesus on using Abobotulinumtoxin A when treating spastic forms of cerebral palsy]. Zhurnal Nevrologii i Psikhiatrii im. S.S. Korsakova, 2016, vol. 116, no. 11, pp. 121-130. (in Russian)

8. Nemkova S.A., Namazova-Baranova L.S., Maslova O.I., Zavadenko N.N., Kholin A.A., Karkashadze G.A., Mamediarov A.M., Nesterovskii Iu.E., Govorun S.V., comp. Detskii tserebralnyi paralich: diagnostika i korrektsiia kognitivnykh narushenii : ucheb.metod.posobie [Cerebral Palsy : Diagnosis and Correction of Cognitive Disorders : technique manual]. GBOU VPO Ros. Nats. Issled. Med. Un-t im. N.I. Pirogova. M., Soiuz Pediatrov Rossii, 2012, 60 p. (in Russian)

9. Horstmann H.M., Bleck E.E. Orthopaedic management in cerebral palsy. $2^{\text {nd }}$ Ed. London, Mac Keith Press, 2007, 412 p.

10.Hurley D.S., Sukal-Moulton T., Msall M.E., Gaebler-Spira D., Krosschell K.J., Dewald J.P. The cerebral palsy research registry: development and progress toward national collaboration in the United States. J. Child. Neurol., 2011, vol. 26, no. 12, pp. $1534-1541$. DOI: $10.1177 / 0883073811408903$.

11.Rosenbaum P.L., Palisano R.J., Bartlett D.J., Galuppi B.E., Russell D.J. Development of the Gross Motor Function Classification System for cerebral palsy. Dev. Med. Child. Neurol., 2008, vol. 50, no. 4, pp. 249-253. DOI: 10.1111/j.1469-8749.2008.02045.x.

12.Aiona M.D., Sussman M.D. Treatment of spastic diplegia in patients with cerebral palsy: Part II. J. Pediatr. Orthop. B, 2004 , vol. 13, no. 3, pp. S13-S38.

13.Damiano D.L., Alter K.E., Chambers H. New clinical and research trends in lower extremity management for ambulatory children with cerebral palsy. Phys. Med. Rehabil. Clin. N. Am., 2009, vol. 20, no. 3, pp. 469-491. DOI: 10.1016/j.pmr.2009.04.005.

14.Lebarbier P., Penneçot G. L'infirmité motrice d’origine cérébrale (IMOC). Rev. Chir. Orthop. Traumatol., 2006, vol. 92, no. 4, pp. 393-395. DOI: RCO-06-2006-92-4-0035-8211-1040-101019-200518541.

15.Novacheck T.F., Stout J.L., Gage J.R., Schwartz M.H. Distal femoral extension osteotomy and patellar tendon advancement to treat persistent crouch gait in cerebral palsy. Surgical technique. J. Bone Joint Surg. Am., 2009, vol. 91, no. Suppl. 2, pp. 271-286. DOI: $10.2106 / J B J S . I .00316$.

16.Viehweger E., Robitail S., Rohon M.A., Jacquemier M., Jouve J.L., Bollini G., Simeoni M.C. Measuring quality of life in cerebral palsy children. Ann. Readapt. Med. Phys., 2008, vol. 51, no. 2, pp. 119-137. DOI: 10.1016/j.annrmp.2007.12.002.

17.Popkov D.A., Zmanovskaia V.A., Gubina E.B., Leonchuk S.S., Butorina M.N., Pavlova O.L. Rezultaty mnogourovnevykh odnomomentnykh ortopedicheskikh operatsii i rannei reabilitatsii v komplekse s botulinoterapiei u patsientov so spasticheskimi formami tserebralnogo paralicha [Results of multilevel orthopedic surgeries and early rehabilitation in combination with Botulinum therapy in patients with spastic cerebral palsy]. Zhurnal Nevrologii i Psikhiatrii im. S.S. Korsakova, 2015, vol. 115, no. 4, pp. 41-48. (in Russian) 
18.Leonchuk S.S., Chibirov G.M., Popkov D.A. Korrekciya deformacii stopy po metodike Evans u rebenka s DCP v ramkah odnomomentnogo mnogourovnevogo ortopedicheskogo vmeshatel'stva. Sluchaj iz praktiki. Genij ortopedii. 2016. no. 3. pp. 77-83. (In Russian)

19.DeLuca P.A., Davis R.B. $3^{\text {rd }}$, Ounpuu S., Rose S., Sirkin R. Alterations in surgical decision making in patients with cerebral palsy based on three-dimensional gait analysis. J. Pediatr. Orthop., 1997, vol. 17, no. 5, pp. 608-614.

20.Gage J.R. The treatment of gait problems in cerebral palsy. Series: Clinics in developmental medicine. London, Mac Keith Press, 2004, no. 164-165.

21.Ounpuu S., DeLuca P., Davis R., Romness M. Long-term effects of femoral derotation osteotomies: an evaluation using threedimensional gait analysis. J. Pediatr. Orthop., 2002, vol. 22, no. 2, pp. 139-145.

22.Rodda J., Graham H.K. Classification of gait patterns in spastic hemiplegia and spastic diplegia: a basis for a management algorithm. Eur. J. Neurol., 2001, vol. 8, no. Suppl. 5, pp. 98-108.

23.Sutherland D.H., Davids J.R. Common gait abnormalities of the knee in cerebral palsy. Clin. Orthop. Relat. Res., 1993, no. 288, pp. 139-147.

24.Lofterød B., Terjesen T., Skaaret I., Huse A.B., Jahnsen R. Preoperative gait analysis has a substantial effect on orthopedic decision making in children with cerebral palsy: comparison between clinical evaluation and gait analysis in 60 patients. Acta Orthop., 2007, vol. 78 , no. 1 , pp. $74-80$.

25.Simon S.R. Quantification of human motion: gait analysis-benefits and limitations to its application to clinical problems. J. Biomech., 2004, vol. 37, no. 12, pp. 1869-1880.

26.Aksenov A.Yu., Heath G.H., Klishkovskaya T.A., Dolganova T.I. Optimising video-based data capture for pathological gait analysis in children with cerebral palsy using a limited number of retro-reflective cameras (literature review). Genij Ortopedii, 2019, T. 25, No 1, pp. 102-110. DOI 10.18019/1028-4427-2019-25-1-102-110. (In Russian)

27.Hillman S.J., Hazlewood M.E., Schwartz M.H., Van der Linden M.L., Robb J.E. Correlation of the Edinburgh Gait Score with the Gillette Gait Index, the Gillette Functional Assessment Questionnaire, and dimensionless speed. J. Pediatr. Orthop., 2007, vol. 27, no. 1 , pp. $7-11$.

28.Novacheck T.F., Stout J.L., Tervo R. Reliability and validity of the Gillette Functional Assessment Questionnaire as an outcome measure in children with walking disabilities. J. Pediatr. Orthop., 2000, vol. 20, no. 1, pp. 75-81.

29.Schwartz M.H., Viehweger E., Stout J., Novacheck T.F., Gage J.R. Comprehensive treatment of ambulatory children with cerebral palsy: an outcome assessment. J. Pediatr. Orthop., 2004, vol. 24, no. 1, pp. 45-53.

30.Read H.S., Hazlewood M.E., Hillman S.J., Prescott R.J., Robb J.E. Edinburgh visual gait score for use in cerebral palsy. J. Pediatr. Orthop., 2003, vol. 23, no. 3, pp. 296-301.

31.Adolfsen S.E., Ounpuu S., Bell K.J., DeLuca P.A. Kinematic and kinetic outcomes after identical multilevel soft tissue surgery in children with cerebral palsy. J. Pediatr. Orthop., 2007, vol. 27, no. 6, pp. 658-667.

32.Lofterød B., Terjesen T. Local and distant effects of isolated calf muscle lengthening in children with cerebral palsy and equinus gait. J. Child. Orthop., 2008, vol. 2, no 1, pp. 55-61. DOI: 10.1007/s11832-007-0074-9.

33.Saraph V., Zwick E.B., Zwick G., Steinwender C., Steinwender G., Linhart W. Multilevel surgery in spastic diplegia: evaluation by physical examination and gait analysis in 25 children. J. Pediatr. Orthop., 2002, vol. 22, no. 2, pp. 150-157.

34.Zwick E.B., Saraph V., Linhart W.E., Steinwender G. Propulsive function during gait in diplegic children: evaluation after surgery for gait improvement. J. Pediatr. Orthop. B, 2001, vol. 10, no. 3, pp. 226-233.

35.Gorton G.E. 3rd, Stout J.L., Bagley A.M., Bevans K., Novacheck T.F., Tucker C.A. Gillette Functional Assessment Questionnaire 22-item skill set: factor and Rasch analyses. Dev. Med. Child. Neurol., 2011, vol. 53, no. 3, pp. 250-255. DOI: 10.1111/j.14698749.2010.03832.x.

36.Durkin M.S., Benedict R.E., Christensen D., Dubois L.A., Fitzgerald R.T., Kirby R.S., Maenner M.J., Van Naarden Braun K., Wingate M.S., Yeargin-Allsopp M. Prevalence of Cerebral Palsy among 8-Year-Old Children in 2010 and Preliminary Evidence of Trends in Its Relationship to Low Birthweight. Paediatr. Perinat. Epidemiol., 2016, vol. 30, no. 5, pp. 496-510. DOI: 10.1111/ ppe.12299.

37.Graham H.K., Rosenbaum P., Paneth N., Dan B., Lin J.P., Damiano D.L., Becher J.G., Gaebler-Spira D., Colver A., Reddihough D.S., Crompton K.E., Lieber R.L. Cerebral palsy. Nat. Rev. Dis. Primers, 2016, vol. 2, pp. 15082. DOI: 10.1038/nrdp.2015.82.

38.Craig J.J., van Vuren J. The importance of gastrocnemius recession in the correction of equinus deformity in cerebral palsy. J. Bone Joint Surg. Br., 1976, vol. 58, no. 1, pp. 84-87.

39.Karamitopoulos M.S., Nirenstein L. Neuromuscular Foot: Spastic Cerebral Palsy. Foot Ankle Clin., 2015, vol. 20, no. 4, pp. 657668. DOI: 10.1016/j.fcl.2015.07.008.

40.Nordmark E., Hägglund G., Lauge-Pedersen H., Wagner P., Westbom L. Development of lower limb range of motion from early childhood to adolescence in cerebral palsy: a population-based study. BMC Med., 2009, vol. 7, pp. 65. DOI: 10.1186/1741-70157-65.

41.Bennet G.C., Rang M., Jones D. Varus and valgus deformities of the foot in cerebral palsy. Dev. Med. Child. Neurol., 1982, vol. 24, no. 4 , pp. 499-503.

42.De Coulon G., Turcot K., Canavese F., Dayer R., Kaelin A., Ceroni D. Talonavicular arthrodesis for the treatment of neurological flat foot deformity in pediatric patients: clinical and radiographic evaluation of 29 feet. J. Pediatr. Orthop., 2011, vol. 31, no. 5, pp. 557-563. DOI: 10.1097/BPO.0b013e31821fffa0.

43.Frost N.L., Grassbaugh J.A., Baird G., Caskey P. Triple arthrodesis with lateral column lengthening for the treatment of planovalgus deformity. J. Pediatr. Orthop., 2011, vol. 31, no. 7, pp. 773-782. DOI: 10.1097/BPO.0b013e31822d3882.

44.Fulford G.E. Surgical management of ankle and foot deformities in cerebral palsy. Clin. Orthop. Relat. Res., 1990, no. 253, pp. 55-61.

45.Grice D.S. An extra-articular arthrodesis of the subastragalar joint for correction of paralytic flat feet in children. J. Bone Joint Surg. Am., 1952, vol. 34 A, no. 4, pp. 927-940.

46.Kołodziej Ł., Dobiecki K., Sadlik B. Surgical treatment of advanced, stiff neurologic cavovarus foot in adults. Ortop. Traumatol. 
Rehabil., 2013, vol. 15, no. 4, pp. 325-333. DOI: 10.5604/15093492.1073831.

47.Ławniczak D., Jóźwiak M., Manikowska F. Assessment of absolute knee joint linear and angular velocity in patients with spastic cerebral palsy after operative treatment of lever arm disfunction deformities - prospective study. Chir. Narzadow Ruchu. Ortop. Pol., 2010, vol. 75, no. 2, pp. 92-97.

48.Mosca V.S. Calcaneal lengthening for valgus deformity of the hind foot. Results in children who had severe, symptomatic flatfoot and skewfoot. J. Bone Joint Surg. Am., 1995, vol. 77, no. 4, pp. 500-512.

49.Radler C., Kranzl A., Manner H.M., Höglinger M., Ganger R., Grill F. Torsional profile versus gait analysis: consistency between the anatomic torsion and the resulting gait pattern in patients with rotational malalignment of the lower extremity. Gait Posture, 2010, vol. 32, no. 3, pp. 405-410. DOI: 10.1016/j.gaitpost.2010.06.019.

50.Sees J.P., Miller F. Overview of foot deformity management in children with cerebral palsy. J. Child. Orthop., 2013, vol. 7, no. 5, pp. 373-377. DOI: 10.1007/s11832-013-0509-4.

51.Yoo W.J., Chung C.Y., Choi I.H., Cho T.J., Kim D.H. Calcaneal lengthening for the planovalgus foot deformity in children with cerebral palsy. J. Pediatr. Orthop., 2005, vol. 25, no. 6, pp. 781-785.

52.Kay R.M., Rethlefsen S.A., Ryan J.A., Wren T.A. Outcome of gastrocnemius recession and tendo-achilles lengthening in ambulatory children with cerebral palsy. J. Pediatr. Orthop. B, 2004, vol. 13, no. 2, pp. 92-98.

53.Baddar A., Granata K., Damiano D.L., Carmines D.V., Blanco J.S., Abel M.F. Ankle and knee coupling in patients with spastic diplegia: effects of gastrocnemius-soleus lengthening. J. Bone Joint Surg. Am., 2002, vol. 84, no. 5, pp. 736-744.

54.Dietz F.R., Albright J.C., Dolan L. Medium-term follow-up of Achilles tendon lengthening in the treatment of ankle equinus in cerebral palsy. Iowa Orthop. J., 2006, vol. 26, pp. 27-32.

55.Gorton G.E. 3rd, Abel M.F., Oeffinger D.J., Bagley A., Rogers S.P., Damiano D., Romness M., Tylkowski C. A prospective cohort study of the effects of lower extremity orthopaedic surgery on outcome measures in ambulatory children with cerebral palsy. J. Pediatr. Orthop., 2009, vol. 29, no. 8, pp. 903-909. DOI: 10.1097/BPO.0b013e3181c11c0c.

56.Miller F. Cerebral Palsy. $1^{\text {st }}$ Ed. New York, Springer-Verlag, 2005. DOI: 10.1007/b138647.

57.Borton D.C., Walker K., Pirpiris M., Nattrass G.R., Graham H.K. Isolated calf lengthening in cerebral palsy. Outcome analysis of risk factors. J. Bone Joint Surg. Br., 2001, vol. 83, no. 3, pp. 364-370.

58.Segal L.S., Thomas S.E., Mazur J.M., Mauterer M. Calcaneal gait in spastic diplegia after heel cord lengthening: a study with gait analysis. J. Pediatr. Orthop., 1989, vol. 9, no. 6, pp. 697-701.

59.Rose S.A., DeLuca P.A., Davis R.B. 3rd, Ounpuu S., Gage J.R. Kinematic and kinetic evaluation of the ankle after lengthening of the gastrocnemius fascia in children with cerebral palsy. J. Pediatr. Orthop., 1993, vol. 13, no. 6, pp. 727-732.

60.Terjesen T., Lofterød B., Skaaret I. Gait improvement surgery in ambulatory children with diplegic cerebral palsy. Acta Orthop., 2015, vol. 86, no. 4, pp. 511-517. DOI: 10.3109/17453674.2015.1011927.

61.Theologis T. Lever arm dysfunction in cerebral palsy gait. J. Child. Orthop., 2013, vol. 7, no. 5, pp. 379-382. DOI: 10.1007/s11832013-0510-y.

62.Putz C., Wolf S.I., Geisbüsch A., Niklasch M., Döderlein L., Dreher T. Femoral derotation osteotomy in adults with cerebral palsy. Gait Posture, 2016, vol. 49, pp. 290-296. DOI: 10.1016/j.gaitpost.2016.06.034.

63.Lofterød B., Terjesen T. Changes in lower limb rotation after soft tissue surgery in spastic diplegia. Acta Orthop., 2010, vol. 81, no. 2, pp. 245-249. DOI: 10.3109/17453671003587135.

64.Gannotti M.E., Gorton G.E. 3rd, Nahorniak M.T., Masso P.D. Walking abilities of young adults with cerebral palsy: changes after multilevel surgery and adolescence. Gait Posture, 2010, vol. 32, no. 1, pp. 46-52. DOI: 10.1016/j.gaitpost.2010.03.002.

65.Lehtonen K., Mäenpää H., Piirainen A. Does single-event multilevel surgery enhance physical functioning in the real-life environment in children and adolescents with cerebral palsy (CP)?: patient perceptions five years after surgery. Gait Posture, 2015, vol. 41, no. 2, pp. 448-153. DOI: 10.1016/j.gaitpost.2014.11.005.

66.Opheim A., McGinley J.L., Olsson E., Stanghelle J.K., Jahnsen R. Walking deterioration and gait analysis in adults with spastic bilateral cerebral palsy. Gait Posture, 2013, vol. 37, no. 2, pp. 165-171. DOI: 10.1016/j.gaitpost.2012.06.032.

Received: 05.04.2019

\section{Information about the authors:}

1. Georgy M. Chibirov, M.D.,

Russian Ilizarov Scientific Centre for Restorative Traumatology and Orthopaedics, Kurgan, Russian Federation

2. Tamara I. Dolganova, M.D., Ph.D.,

Russian Ilizarov Scientific Center for Restorative Traumatology and Orthopaedics, Kurgan, Russian Federation, Email: rjik532007@rambler.ru

3. Dmitrii V. Dolganov, Ph.D. of Biological Sciences,

Russian Ilizarov Scientific Center for Restorative Traumatology and Orthopaedics, Kurgan, Russian Federation

4. Siniša Ducič, M.D., Ph.D.,

Children's University Hospital, Belgrade, Serbia

5. Dmitry A. Popkov, M.D., Ph.D., Professor of RAS,

Russian Ilizarov Scientific Centre for Restorative Traumatology and Orthopaedics, Kurgan, Russian Federation, Email: dpopkov@mail.ru 